\title{
Microwave Polyol Synthesis of Pt/C Catalyst and its Application to Hydrolysis of Sodium Borohydride
}

\author{
Dongyan Xu*, Haizhen Wang, Ping Dai and Qingguo Ye \\ College of Chemical Engineering, Qingdao University of Science and Technology, Qingdao 266042, P.R. China
}

\begin{abstract}
XC-72 carbon supported Pt catalyst was prepared by using a microwave heated ethylene glycol method and characterized by transmission electron microscopy (TEM) and X-ray diffraction (XRD). For comparison, the same $\mathrm{Pt} / \mathrm{XC}$ 72 catalyst was also prepared by conventional heated ethylene glycol method. TEM image showed that microwave synthesized Pt nanoparticles were uniformly dispersed on the surface of carbon and had a narrow size distribution. The average particle sizes of Pt nanoparticles synthesized with microwave irradiation and conventional heating method are 2.7 and $3.7 \mathrm{~nm}$, respectively. The Pt/C catalysts exhibited four diffraction peaks that are indexed to the $\left\{\begin{array}{llllll}1 & 1 & 1\end{array}\right\},\left\{\begin{array}{lllll}2 & 0 & 0\end{array}\right\},\left\{\begin{array}{lll}2 & 2 & 0\end{array}\right\}$, and $\left\{\begin{array}{lll}3 & 1 & 1\end{array}\right\}$ planes of Pt. Their catalytic performances were evaluated by hydrolysis of sodium borohydride. The microwave synthesized Pt/XC-72 catalyst exhibited higher catalytic activity than that synthesized with conventional heated ethylene glycol method.
\end{abstract}

Keywords: Catalyst, nanocomposites, ethylene glycol, microwave.

\section{INTRODUCTION}

Recently, the hydrolysis of sodium borohydride $\left(\mathrm{NaBH}_{4}\right)$ has attracted considerable attentions as a hydrogen source for proton exchange membrane fuel cells (PEMFCs) owing to its combined advantages [1]. To control the hydrogen generation rate, the precious catalysts, such as ruthenium nanoparticles [2,3], resin-supported ruthenium [4,5], and $\mathrm{LiCoO}_{2}$ supported platinum [6], have been demonstrated to exhibit high activities in the hydrolysis reaction. It is obvious that the nano-sized metal particles would be very difficult to recover and handle at industrial level. It was also found that the ion-exchange resin beads supported $\mathrm{Ru}$ catalyst were broken up into fine particles and gave rise to uncontrollable generation of hydrogen when a high concentration of $\mathrm{NaBH}_{4}$ (20\%) was used [7].

Carbons are stable in both acidic and basic media and make them among the most attractive supports for hydrolysis reaction in which the catalysts are usually exposed to a hot caustic environment. It has been found that $\mathrm{Pt}$ metal catalysts supported on Vulcan XC-72R carbon [8] and activated carbon [9] displayed excellent hydrogen generation performances in hydrolysis of $\mathrm{NaBH}_{4}$. To improve the metal particle dispersion, the polyol (most commonly ethylene glycol) process has been used in preparing carbon supported Pt catalysts for fuel cell applications [10,11].

In this study, Pt nanoparticles supported on carbon were prepared by the ethylene glycol (EG) process. To thermally activate EG, microwave irradiation was adopted. The asprepared catalyst was thus used to catalyze the hydrolysis of sodium borohydride. The particle size distribution, average diameter and the catalytic performance of the microwave

*Address correspondence to this author at the College of Chemical Engineering, Qingdao University of Science and Technology, Qingdao 266042, P.R. China; Tel: +86 532 84022506; Fax: +86 532 84022757;

E-mail: xdy0156@sina.com.cn synthesized $\mathrm{Pt} / \mathrm{C}$ catalyst were compared with that prepared with conventional heated EG method.

\section{EXPERIMENTAL SECTION}

\subsection{Catalyst Preparation}

$\mathrm{Pt} / \mathrm{C}$ catalyst was prepared by microwave heating of $\mathrm{EG}$ solutions of Pt salt. Vulcan XC-72 carbon (Cabot Corp., Specific surface area $(B E T)=235 \mathrm{~m}^{2} / \mathrm{g}$ ) was used as the support. The synthesis was carried out with the aid of an industrial microwave oven (Nanjing Jiequan Microwave Equipment Co. Ltd, 700W). As a typical process for the synthesis of $\mathrm{Pt} / \mathrm{C}$ catalyst with the Pt loading of $15 \mathrm{wt} \%, 400 \mathrm{mg}$ of Vulcan XC-72 carbon was added in $100 \mathrm{ml}$ of EG and ultrasonicated for $30 \mathrm{~min}$. Then, $10 \mathrm{ml}$ of $\mathrm{H}_{2} \mathrm{PtCl}_{6} / \mathrm{EG}(60$ $\mathrm{mg} \mathrm{Pt}$ ) was slowly added. The further treatment was performed by slow addition of $2 \mathrm{M} \mathrm{NaOH} / \mathrm{EG}$ solution until the $\mathrm{pH}$ value of the mixture was adjusted to above 12 and ultrasonicated. The suspension was exposed to microwave irradiation at $170{ }^{\circ} \mathrm{C}$ for $1 \mathrm{~min}$, and then cooled to room temperature. The product was recovered by centrifugation and dried in a vacuum oven at $80{ }^{\circ} \mathrm{C}$ for $10 \mathrm{~h}$. For comparison, the $\mathrm{Pt} / \mathrm{C}$ catalyst was also prepared by heating of EG solutions of Pt salt with an oil bath at $130{ }^{\circ} \mathrm{C}$ for $3 \mathrm{~h}$. The $\mathrm{Pt} / \mathrm{C}$ catalysts prepared by microwave irradiation and oil bath methods are denoted as $\mathrm{Pt} / \mathrm{C}-\mathrm{M}$ and $\mathrm{Pt} / \mathrm{C}-\mathrm{O}$, respectively.

\subsection{Catalyst Characterization}

XRD analyses were performed using a Rigaku diffractometer (D/max-2400 X) with a $\mathrm{Cu} \mathrm{K} \alpha$ radiation source.

Transmission electron microscopy (TEM) images were recorded on a JEOL JEM-2000EX microscope operated at $100 \mathrm{kV}$. Particle size distributions for the catalysts were obtained by manually measuring 100 particles from the micrographs. The number-averaged particle diameter $d_{\mathrm{m}}$ was calculated by the following formula: 
$d_{m}=\sum_{i} n_{i} d_{i} / \sum_{i} n_{i}$

where $n_{i}$ is the number of particles with diameter $d_{i}$.

\subsection{Catalyst Testing}

The catalytic activity of $\mathrm{Pt} / \mathrm{C}$ catalysts was determined by measuring the amount of hydrogen generated from the $\mathrm{NaOH}$-stabilized aqueous $\mathrm{NaBH}_{4}$ solution. In a typical batch hydrogen generation experiment, $10 \mathrm{ml} 5 \% \mathrm{NaBH}_{4}-1 \%$ $\mathrm{NaOH}$ solution was initially put into the flask. The starting point of the reaction is defined as the time when a certain quantity of $\mathrm{Pt} / \mathrm{C}$ catalyst was added to the flask. The solution temperature was kept constant within the range of the set value $\pm 0.2{ }^{\circ} \mathrm{C}$ using a water bath. During the catalytic hydrolysis reaction, a flowmeter was adopted to record the cumulative volume of the generated $\mathrm{H}_{2}$. For a successive experiment, a tubular reactor was adopted. A certain amount of catalyst was placed in the reactor prior to the reaction. The system was sealed, and then $10 \% \mathrm{NaBH}_{4}-5 \% \mathrm{NaOH}$ solution was pumped from a storage tank into the reactor with a certain flow rate $\left(4-6 \mathrm{~mL} \mathrm{~min}^{-1}\right)$. The generated hydrogen, the by-product and the residual reactant solution were imported into a gas-liquid separator. The rest processes were similar to the intermittent reactions.

\section{RESULTS AND DISCUSSION}

\subsection{Characterization of $\mathrm{Pt} / \mathrm{C}$ Catalysts}

Fig. (1). shows the TEM images of both the microwave and oil bath prepared $\mathrm{Pt} / \mathrm{C}$ catalysts. It can be observed that the microwave prepared $\mathrm{Pt}$ nanoparticles are uniformly dispersed on the surface of carbon. The Pt particle size distribution of Pt/C-W and Pt/C-O catalysts is shown in Fig. (2). As shown in Fig. (2), the microwave synthesized Pt nanoparticles have a narrow particle size distribution raging from 1.0 to $5.0 \mathrm{~nm}$, with the average diameter of about $2.7 \mathrm{~nm}$. The $\mathrm{Pt}$ nanoparticles prepared with conventional heating (oil bath in this study) method, by comparison, have a relatively broad particle size distribution raging from 1.0 to $7.0 \mathrm{~nm}$, with the average diameter of $3.7 \mathrm{~nm}$.

Fig. (3). shows the powder XRD patterns of $\mathrm{P} t / \mathrm{C}-\mathrm{W}$ and $\mathrm{Pt} / \mathrm{C}-\mathrm{O}$ catalysts. The diffraction peak at $2 \theta=25^{\circ}$ could be attributed to the graphite structure (002) of XC-72 carbon. For both $\mathrm{Pt} / \mathrm{C}-\mathrm{M}$ and $\mathrm{Pt} / \mathrm{C}-\mathrm{O}$ catalysts, the nanocomposites exhibit only characteristic diffraction peaks of the facecentered cubic platinum. The major peaks centre at $2 \theta=$ $39.7^{\circ}\left(\begin{array}{lll}1 & 1 & 1\end{array}\right), 45.6^{\circ}\left(\begin{array}{lll}2 & 0 & 0\end{array}\right), 67.4^{\circ}\left(\begin{array}{lll}2 & 2 & 0\end{array}\right)$, and $80.5^{\circ}\left(\begin{array}{lll}3 & 1 & 1\end{array}\right)$. The average crystallite sizes for the $\mathrm{Pt} / \mathrm{C}-\mathrm{W}$ and $\mathrm{Pt} / \mathrm{C}-\mathrm{O}$ catalysts, calculated by Scherrer's formula, are 3.1 and $4.0 \mathrm{~nm}$, respectively. These data are comparable with those obtained by TEM images.

It is generally agreed that the size of metal nanoparticles is determined by the rate of reduction of the metal precursor. At high temperatures, ethylene glycol is decomposed to yield in situ reducing species, $\mathrm{CH}_{3} \mathrm{CHO}$, for the reduction of the metal ions to metallic particles [12]. The formation of $\mathrm{Pt}$ nanoparticles initiates from the following reactions in EG solution under microwave heating [13].

$$
\begin{aligned}
& \mathrm{CH}_{2} \mathrm{OH}-\mathrm{CH}_{2} \mathrm{OH} \rightarrow \mathrm{CH}_{3} \mathrm{CHO}+\mathrm{H}_{2} \mathrm{O} \\
& 4 \mathrm{CH}_{3} \mathrm{CHO}+\mathrm{Pt}^{4+} \rightarrow \mathrm{Pt}+4 \mathrm{H}^{+}+2 \mathrm{CH}_{3} \mathrm{COCOCH}_{3}
\end{aligned}
$$
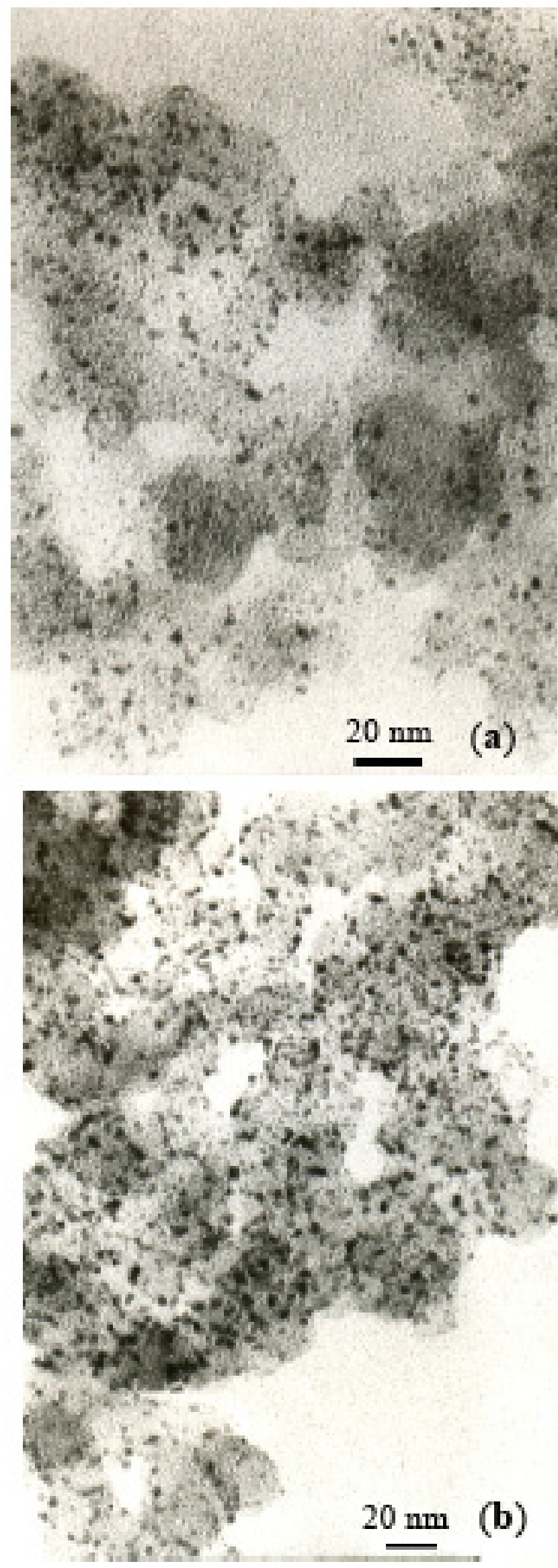

Fig. (1). TEM images of (a) Pt/C-W and (b) Pt/C-O catalysts. 


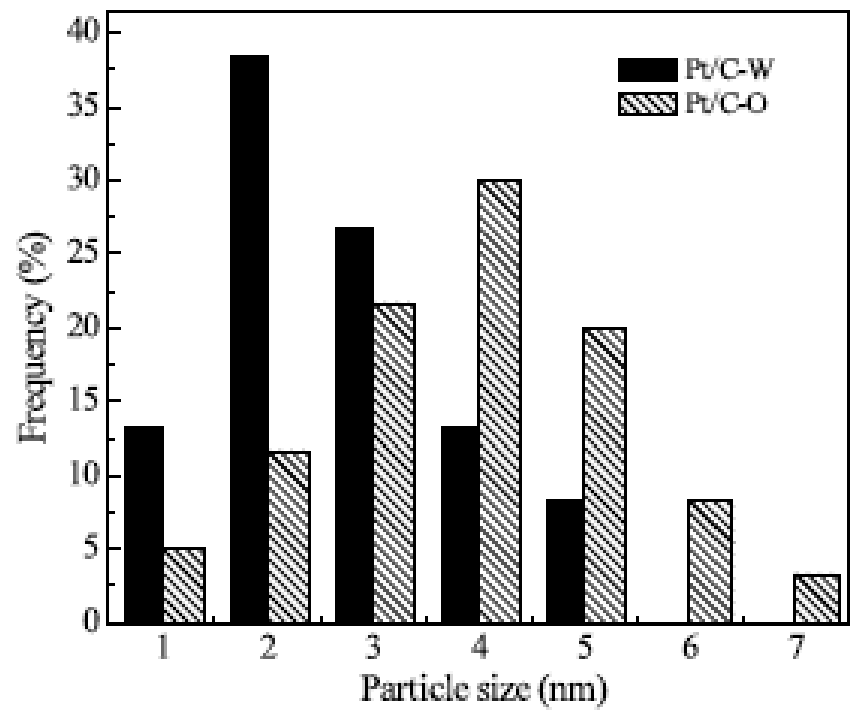

Fig. (2). Histograms of metal particles diameters for (a) $\mathrm{Pt} / \mathrm{C}-\mathrm{W}$ and (b) Pt/C-O catalysts.

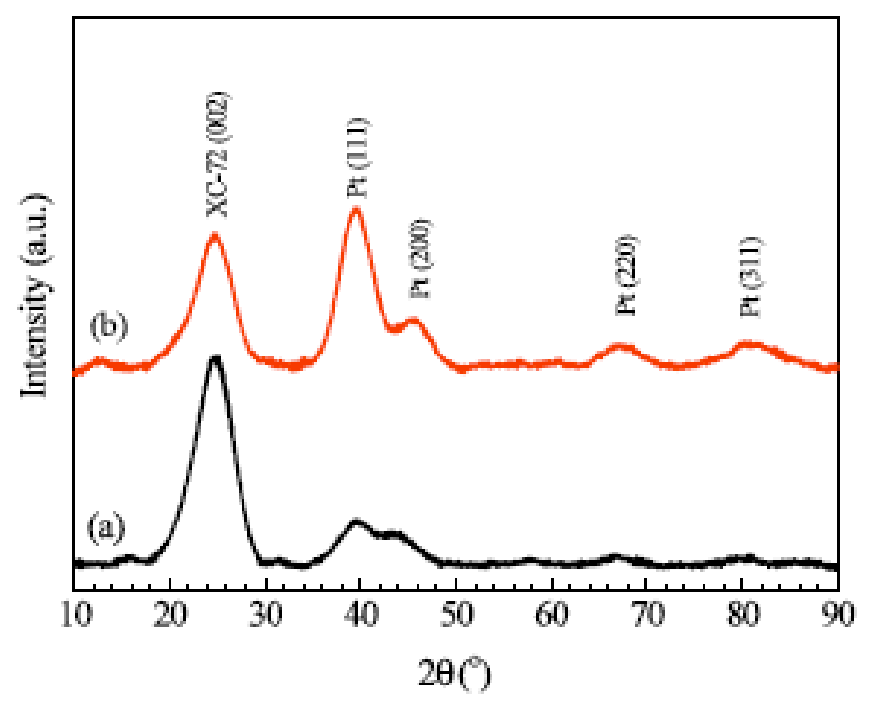

Fig. (3). Powder XRD patterns of (a) $\mathrm{Pt} / \mathrm{C}-\mathrm{W}$ and (b) $\mathrm{Pt} / \mathrm{C}-\mathrm{O}$ catalysts.

Unlike the convectional conductive heating with an inherent heterogeneous temperature distribution, the microwave irradiation can provide fast and uniform heating through dielectric losses [10]. The fast heating by microwave accelerates the reduction of the metal precursor and the nucleation of the metal clusters. It is obvious that the fast nucleation of the metal clusters restrains the further growing of metal clusters, and thus promotes the formation of small particles. It has been suggested that the carbon surface may contain sites suitable for heterogeneous nucleation and the presence of a carbon surface also interrupts particle growth [14]. On the other hand, the homogeneous microwave heating of liquid samples can generate a more uniform environment for the nucleation and growth of metal particles, and this of course contributes to the resulting narrow particle size distribution. In a word, the small particle size and the homogeneous size distribution of $\mathrm{Pt} / \mathrm{C}-\mathrm{W}$ catalyst are ascribed to the rapid reduction of the metal salts and the formation of metallic nuclei in the mixture of EG solution facilitated by microwave irradiation. It is worth to note that most researchers used domestic microwaves to complete the heating in the polyol process $[10,15,16]$, one major deficiency of which is that the temperature of the mixture of polyol solution, platinum salt and support, may vary with the volume of the mixture, irradiation time, the power of the oven, etc. In contrast to, we use an industrial microwave with an infrared thermometer sensor, by which the temperature of the mixture can be easily observed, and therefore a satisfactory control of the reduction temperature realized.

\subsection{Catalytic Activity}

Catalytic activities of the $\mathrm{Pt} / \mathrm{C}$ nanocomposites for hydrogen generation from hydrolysis of $\mathrm{NaBH}_{4}$ were investigated in a batch manner and the results were shown in Fig. (4). As seen in Fig. (4), the Pt/C-W catalyst prepared by microwave irradiation method compares favorably with the $\mathrm{Pt} / \mathrm{C}-\mathrm{O}$ catalyst, suggesting the small particles size and high dispersion of Pt metals for $\mathrm{Pt} / \mathrm{C}-\mathrm{W}$ catalyst play a very important role for the improvement in catalytic activity.

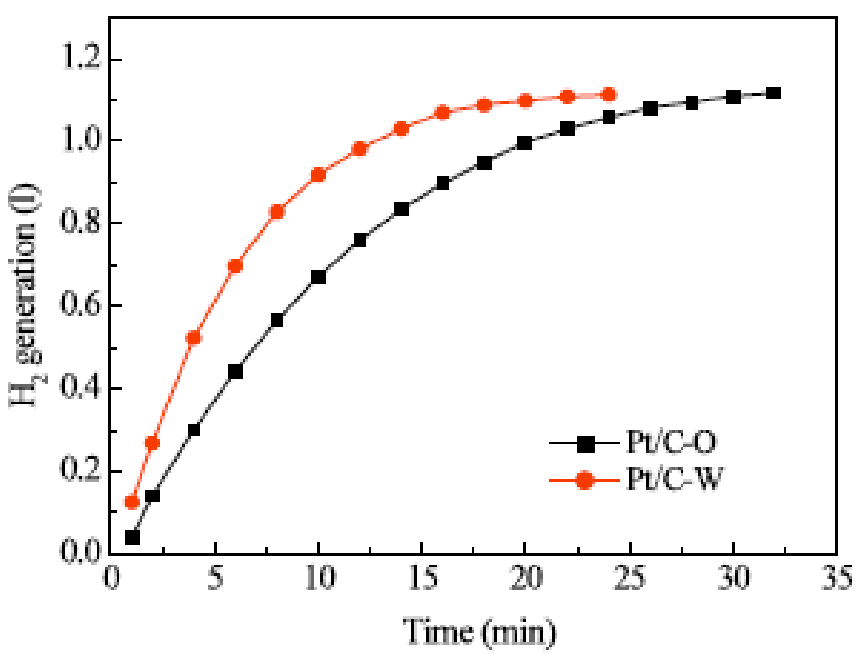

Fig. (4). Accumulated hydrogen production at $25{ }^{\circ} \mathrm{C}$ using $0.020 \mathrm{~g}$ of $\mathrm{Pt} / \mathrm{C}-\mathrm{W}$ and $\mathrm{Pt} / \mathrm{C}-\mathrm{O}$ catalysts.

To estimate whether the as-prepared catalyst is suitable for application in a hydrogen generator, its successive hydrogen generation performance was also investigated. Fig. (5). shows the successive hydrogen generation performances of $\mathrm{Pt} / \mathrm{C}-\mathrm{W}$ catalyst for a $10 \% \mathrm{NaBH}_{4}-5 \% \mathrm{NaOH}$ solution and constant catalyst loading. When the solution was pumped to the reactor at a rate of $4 \mathrm{ml} \cdot \mathrm{min}^{-1}$, the hydrogen generation rate increased drastically in the first few minutes due to the contact between the sodium borohydride and the catalyst, and then reached a maximum steady value. However, when the feeding flow rate was increased to $6 \mathrm{ml} \cdot \mathrm{min}^{-1}$, the hydrogen generation rate increased first and then decreased until a steady value was obtained. The steady hydrogen generation rate is close to that at the feeding flow rate of $5 \mathrm{ml} \cdot \mathrm{min}^{-1}$. These results suggested that a higher feeding flow rate may induce an insufficient reaction.

The $\mathrm{H}_{2}$ generation rate as a function of time for $10 \mathrm{wt} . \%$ $\mathrm{NaBH}_{4}$ solutions and constant feed of $4 \mathrm{ml} / \mathrm{min}$ was shown in Fig. (6). When feeding the $\mathrm{NaBH}_{4}$ solution into the reactor containing $2 \mathrm{~g}$ of $\mathrm{Pt} / \mathrm{C}-\mathrm{W}$ catalyst by switching on the pump, the $\mathrm{H}_{2}$ starts to generate. After about $8 \mathrm{~min}$, the $\mathrm{H}_{2}$ generation rate reaches a constant value. By switching off the pump, the $\mathrm{H}_{2}$ generation ceases rapidly. 


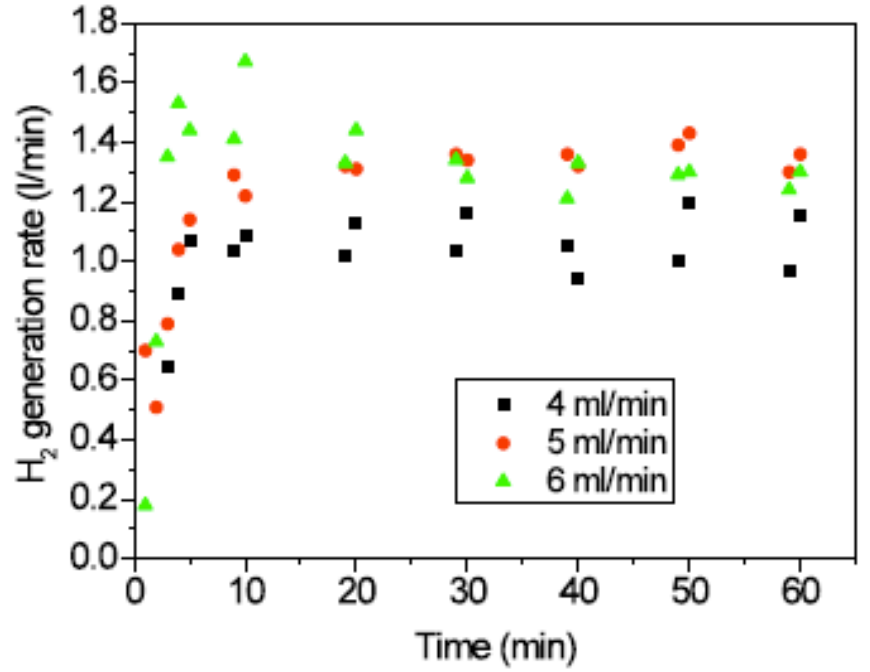

Fig. (5). Successive hydrogen generation as a function of time at different feeding flow rates using $2 \mathrm{~g}$ of $\mathrm{Pt} / \mathrm{C}-\mathrm{W}$ catalyst.

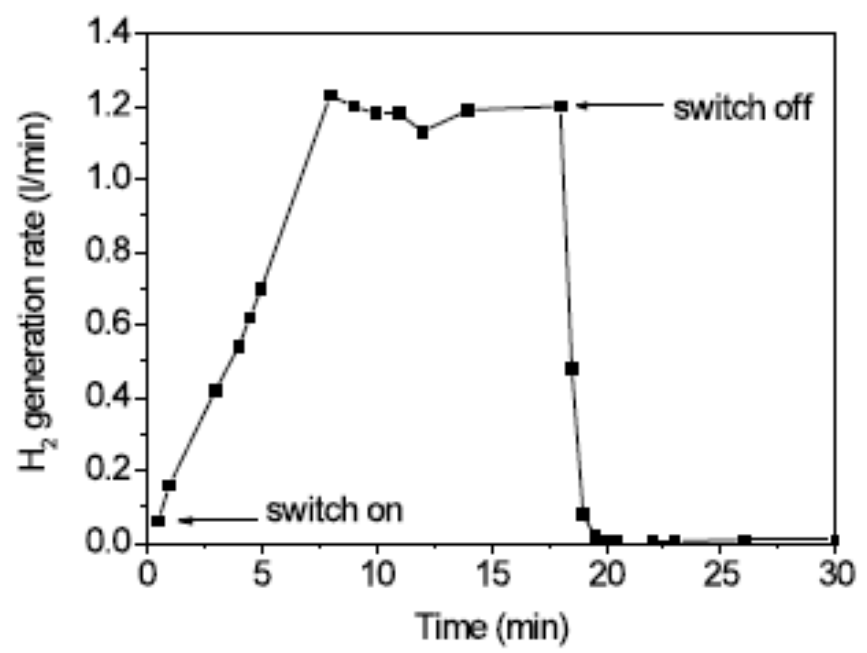

Fig. (6). Response of hydrogen production over $\mathrm{Pt} / \mathrm{C}-\mathrm{W}$ catalyst at feeding flow rate of $4 \mathrm{ml} / \mathrm{min}$.

\section{CONCLUSIONS}

Pt nanoparticles supported on XC-72 carbon were prepared by a heated ethylene glycol process. The characterization results showed that a microwave assisted heating method can synthesize Pt nanoparticles with small particle size and better dispersion over the carbon support, which are mainly ascribed to the rapid reduction of the metal salts and the formation of metallic nuclei in the mixture of EG solution facilitated by microwave irradiation. The as-prepared $\mathrm{Pt} / \mathrm{C}-\mathrm{W}$ catalyst exhibited high performance for hydrogen generation from hydrolysis of $\mathrm{NaBH}_{4}$.

\section{ACKNOWLEDGEMENTS}

The work was supported by the Key Project of Chinese Ministry of Education (No. 208076), and Ph. D foundation of Qingdao University of Science and Technology (No. 0022267).

\section{REFERENCES}

[1] Wee, J.H.; Lee, K.Y.; Kim, S.H. Sodium borohydride as the hydrogen supplier for proton exchange membrane fuel cell systems. Fuel Process. Technol., 2006, $87,811$.

[2] Özkar, S.; Zahmakıran, M. Hydrogen generation from hydrolysis of sodium borohydride using $\mathrm{Ru}(0)$ nanoclusters as catalyst. J. Alloys Compd., 2005, 404-406, 728.

[3] Zahmakıran, M.; Özkar, S. Water dispersible acetate stabilized ruthenium $(0)$ nanoclusters as catalyst for hydrogen generation from the hydrolysis of sodium borohyride. J. Mol. Catal. A, 2006, 258, 95.

[4] Amendola, S.C.; Sharp-Goldman, S.L.; Janjua, M.S.; Spencer, N.C.; Kelly, M.T.; Petillo, P.J.; Binder, M. A safe, portable, hydrogen gas generator using aqueous borohydride solution and Ru catalyst. Int. J. Hydrogen Energy, 2000, 25, 969.

[5] Amendola, S.C.; Sharp-Goldman, S.L.; Janjua, M.S.; Kelly, M.T.; Petillo, P.J.; Binder, M. An ultrasafe hydrogen generator:aqueous, alkaline borohydride solutions and Ru catalyst. J. Power Sources, 2000, 85, 186.

[6] Kojima, Y.; Suzuki, K.; Fukumoto, K.; Sasaki, M.; Yamamoto, T.; Kawai, Y.; Hayashi, H. Hydrogen generation using sodium borohydride solution and metal catalyst coated on metal oxide. Int. J. Hydrogen Energy, 2002, 27, 1029.

[7] Xia, Z.T.; Chan, S.H. Feasibility study of hydrogen generation from sodium borohydride solution for micro fuel cell applications. J. Power Sources, 2005, 152, 46.

[8] Bai, Y.; Wu, C.; Wu, F.; Yi, B.L. Carbon-supported platinum catalysts for on-site hydrogen generation from $\mathrm{NaBH}_{4}$ solution. Mater. Lett., 2006, 60, 2236.

[9] Xu, D.Y.; Ye, W.; Zhang, H.M. Hydrogen generation from hydrolysis of alkaline sodium borohydride solution using $\mathrm{Pt} / \mathrm{C}$ catalyst. Catal. Commun., 2007, 8, 1767.

[10] Chen, W.X.; Lee, J.Y.; Liu, Z.L. Microwave-assisted synthesis of carbon supported Pt nanoparticles for fuel cell applications. Chem. Commun., 2002, 2588

[11] Liang, Y.M.; Zhang, H.M.; Zhong, H.X.; Zhu, X.B.; Tian, Z.Q.; $\mathrm{Xu}, \mathrm{D} . \mathrm{Y}$. Preparation and characterization of carbon-supported PtRuIr catalyst with excellent CO-tolerant performance for protonexchange membrane fuel cells. $J$. Catal., 2006, 238, 468.

[12] Komarneni, S.; Li, D.S.; Newalkar, B.; Katsuki, H.; Bhalla, A.S. Microwave-polyol process for Pt and Ag nanoparticles. Langmuir, $\mathbf{2 0 0 2}, 18,5959$.

[13] Tsuji, M.; Hashimoto, M.; Nishizawa, Y.; Kubokawa, M.; Tsuji, T. Microwave-assisted synthesis of metallic nanostructures in solution. Chem. Eur. J., 2005, 11, 440.

[14] Liu, Z.L.; Hong, L.; Tham, M.P.; Lim, T.H.; Jiang, H.X. Nanostructured $\mathrm{Pt} / \mathrm{C}$ and $\mathrm{Pd} / \mathrm{C}$ catalysts for direct formic acid fuel cells. $J$. Power Sources, 2006, 161, 831.

[15] Liu, Z.L.; Guo, B.; Chan, S.H.; Tang, E.H.; Hong, L. Pt and Ru dispersed on $\mathrm{LiCoO}_{2}$ for hydrogen generation from sodium borohydride solutions. J. Power Sources, 2008, 176, 306.

[16] Huang, J.S.; Zhang, X.G.; Luo, J.M.; Sun, J.Y.; Yang, W.J. Oxygen reduction reaction on $\left(\mathrm{Pt}-\mathrm{NbPO}_{x}\right) / \mathrm{MWCNTs}$ electrodes prepared by microwave irradiation method. J. Solid State Electrochem., 2008, 12, 113. 